International Review of Research in Open and Distributed Learning Volume 16, Number 1

February - 2015

\title{
From the Classroom to the Keyboard: How Seven Teachers Created Their Online Teacher Identities
}

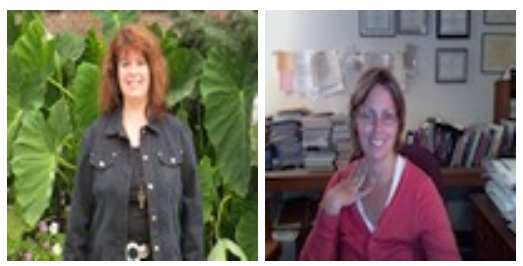

Jennifer C. Richardson and Janet Alsup Purdue University, USA

\begin{abstract}
Teacher identity is defined as a sense of teacher self that results from a productive combination of key personal and professional subjectivities or beliefs. Much empirical research has been done on the development of teacher identity in the K-12 arena, with a great deal of theoretical and philosophical scholarship about teaching at the college level, yet little research to date has looked at how instructors at the college level, especially those who are teaching online, develop their online instructor identity. The purpose of this interview-based, qualitative study is to understand the experience of first time online instructors and how they develop their online teacher identity and utilizes the framework established by Beijaard, Meijer and Verloop (2004) as the lens for analyses. Recommendations are made for cultivating online teacher identity and the many aspects of it as a means to strengthen online teacher identity to not only provide effective and innovative teaching experiences but also for the sake of retention.
\end{abstract}

Keywords: Teacher professional identity; online instruction; preparing online teachers 
Teacher identity can be defined as a sense of teacher self that results from a productive combination of key personal and professional subjectivities, identity positions or beliefs (Alsup, 2006). Such a combination leads to effective and well-motivated conceptions of professional self, which take into consideration both institutional demands and personal priorities. Akkerman and Meijer (2011) define teacher identity as a dialogical process, during which a teacher engages in an "ongoing process of negotiating and interrelating multiple 'I' positions in such a way that a more or less coherent and consistent sense of self is maintained" (p. 315). Much research has been done on the development of teacher identity in the K-12 arena (Alsup, 2006; Britzman, 1991; Danielewicz, 2001; Lortie, 1975) with some theoretical and philosophical scholarship about teaching at the college level (Baxter, 2012), yet little research to date has looked at how instructors at the college level who are specifically teaching at a distance develop their online instructor identity. One notable exception is Baxter (2012) who argues that the existence of "resistance discourses," or discourses that challenge the status quo, are essential to the development of "feelings of self-salience, personal efficacy and confidence" among online instructors (p. 9).

The development of online teaching identity is especially important as online learning in higher education continues to grow exponentially; according to Allen and Seaman's (2013) report of online learning in the US:

- The number of students taking at least one online course increased from the previous year by over 570,000 to a new total of 6.7 million.

- The 9.3 percent growth rate for online enrollments far exceeds the less than two percent growth of the overall higher education student population.

- Thirty-two percent of all higher education students now take at least one course online.

- Close to $70 \%$ of higher education institutions in the US reported that online education was critical to their long-term strategy. (p. 4)

As we have every reason to believe that the numbers of online students and classes, and therefore instructors, will continue to grow, it is important to explore all aspects of online teacher professional development. This includes the notion of professional teacher identity construction, a notion that is often complex, multi-faceted, and individualized.

This qualitative study explores the professional identity development of seven first-time online instructors around the United States, with particular emphasis on their expressed perceptions of their teaching self in an online setting. We argue that several essential elements need to be addressed and balanced in the lives of new online instructors in order for effective teaching and learning to occur, including some control over course design and teaching, attention to projections of teaching persona or presence, developing and maintaining social aspects of the

This work is licensed under a Creative Commons Attribution 4.0 International License. 
course, structure and planning, and effective communication with students. These areas of importance characterize the online teacher identity as significantly and necessarily different from that of a teacher in a face-to-face class; the instructor's sense of teacher self is not an extension of that in a traditional setting, but rather it is a unique creation specific to the online context (Paloff and Pratt, 1999, 2001).

\section{Review of the Literature}

Beauchamp and Thomas (2009) provide an overview of issues related to teacher identity research that have arisen since the 1980s. After reading much of this research, they determined that several issues emerged: problems with identifying identity itself, the role of the self in professional lives, agency, emotion, narrative, discourse, reflection and context (p. 1). They also noted that much of this research focused on new or pre-service K-12 teachers. Beijaard, Meijer, and Verloop (2004) similarly conducted a review of research on teacher identity from 1988-2000 and identified four features that appeared essential for teachers' professional identity to develop productively: professional identity development must be seen as a process, professional identity implies both person and context, professional identity consists of sub identities that should somehow harmonize, and agency, or active participation, is an important element (p. 122). They also determined that in future research on teacher identity more attention should be paid to several identified "gaps": clear definition of terms and more attention to be paid to the context of teachers' work (p. 126).

According to Rogers and Babinski (2002), much has been written about the problems of new secondary school teachers, and ample research has been conducted on the topic (Bell and Gilbert, 1994; Bullough, 1987; Feiman-Nemser, 1983; Fuller, 1969; Grant and Zeichner, 1981; Kestner, 1994; Ryan, 1970; Veenman, 1984; Luehmann and Tinelli, 2008). Yet, Rogers and Babinski state, "despite all of the research and all of the books and articles written about the difficulties endured by beginning teachers, the first year of teaching continues to be an exceptionally difficult time for most of them" (p. 2). Only about 50\% of new K-12 teachers' careers last longer than five years (Gordon, 1991; Huling-Austin, Odell, Ishler, Kay, and Edelfelt, 1989). And, if that isn't bad enough, Robert Bullough (1987) writes, "many of the teachers who remain in classrooms end up teaching in ways that are inconsistent and even contradictory to their initial pedagogical beliefs, goals, and expectations" (quoted in Rogers and Babinski, p. 3).

Much scholarship on teaching at the college level is more theoretical in nature, although equally provocative. Examples include the work of critical pedagogues such as Freire (1970), Apple (1995), hooks (1994), Giroux (2011), Palmer (2007) and Nussbaum (1997). These scholars write of education as liberation and teachers as guides to help students develop critical consciousness of their own socio-cultural contexts and how they might connect knowledge (often as literacy) to power and freedom. They speak of education for self-actualization, often drawing on feminism,

This work is licensed under a Creative Commons Attribution 4.0 International License. 
Marxism, postcolonial studies, queer theory and anti-racist theories, arguing that teachers must develop the approaches and dispositions to be educators who transfer content knowledge, but who also model how such knowledge can improve daily life.

In our research we have found empirical studies of teacher identity at the post-secondary level to be elusive. This lack may not be surprising as college instructors arguably receive less guidance in pedagogy and teaching methods than K-12 teachers (Crawford, 2003; Higher Learning Commission, 2003; Hurtado, Eagan, Pryor, Whang and Tran, 2012; Thompson, 2006). In fact, Adams (2002) points to the research in this area and how it recognizes the impact of the mismatch between graduate training and the multiple academic responsibilities facing new faculty. While universities look to hire 'teaching ready' applicants, the preparation of graduate students is varied from little experience to almost no experience teaching independently (Adams, 2002) with many receiving no formal professional development in teaching (Abraham et al., 1997; DeChenne et al., 2009; Golde and Dore, 2001; Meyers, Lansu, Hundal, Lekkos, and Prieto, 2007; Piccinin and Fairweather, 1996-97; Prieto and Scheel, 2008; Rushin et al., 1997 as cited in Austin, 2002). Similarly, Buckley (2002) discusses what many in academia take as truth in anecdotal form. He talks about how faculty are content experts but

that teaching well requires more than content knowledge...Most faculty were trained researchers, with little formal training in teaching or the cognitive development of learning. [Moreover], faculty cultures often do not encourage or reward faculty development in teaching, so most faculty teach the way that they were taught. (Buckley, 2002, p. 31)

Similarly, Conrad (2004), in her study of online graduate instructors explained, "we teach who we are"; in other words, "each instructor [brings] to his new environment a framework by which to judge what he should do, how he should do it, and what the results should look like" (p. 41).

As already stated, research on the development of university teachers' professional identities (or educators in general, regardless of grade level) is slim. The critical pedagogues mentioned above, however, make many similar arguments about the developing teacher at any level as those writing about teaching in K-12 settings: Being a good teacher involves integrating conflicting subjectivities, dealing with emotions positively, understanding that discourses can create ideological learning spaces, and accepting that a sense of teacher-self is not only discursive but also embodied. For example, Palmer (2007) stressed the importance of a teacher knowing him or herself, in addition to students. He sees teaching as a spiritual endeavor deeply connected to social justice and change. Teaching is about motivating students to excel in their chosen careers while also becoming aware of cultural and social inequalities and how to reverse them. Perhaps the first theorist of social justice education was John Dewey, whose Democracy and Education (1916) theorized the ideal, democratic aims of a public education that works to liberate, rather than indoctrinate.

This work is licensed under a Creative Commons Attribution 4.0 International License. 
As many university teachers may now find themselves shifting from traditional, face-to-face university teaching to teaching in an online environment, undoubtedly there will be parallel shifts in their internalized conceptions of who they are as teachers and what they believe is important to their developing "electronic pedagogy" (Paloff and Pratt, 1999, p. 12). Many argue that with additional online courses in the curriculum we see some university teachers making a shift from teacher-centered to student-centered learning and from passive to active learning, in addition to dealing with new understandings of time management, the use of visual materials and cues, and online communication and presence (Paloff and Pratt, 2002; Hodge, Bosse, Faulconer and Fewell, 2006; Simonson, Smaldino, Albright and Zvacek, 2012; Richardson and Swan, 2003). We believe that this study provides insight into how new online instructors at the university level may become effective, motivated, and reflective teachers through deeper understanding of their professional knowledge and identity development.

\section{Methods}

This study is an interview-based, qualitative study of online teachers' perceptions of their own identity as online instructors in college settings. While past research on teacher identity addressed the issue of teacher professional identity and how to cultivate it at various career stages, we focus specifically on the initial development of online teacher identity among college instructors.

As a framework for understanding teacher professional identity development, we use Beijaard et al's (2004) four essential characteristics of teacher professional identity as they determined from a review of teacher identity research: "professional identity as an ongoing process of interpretation and re-interpretation of experiences (Kerby, 1991)," "professional identity implying both person and context," "a teacher's professional identity consists of sub-identities that more or less harmonize," and "Agency is an important element of professional identity" (p. 122-123). These four characteristics encapsulate the findings of most of the previous research on teacher identity development, albeit most of it not specifically related to online teaching. In their review of research, Beijaard et al called for additional studies that pay more attention to teaching context when speaking of the development of teacher professional identity; our study specifically focuses on the context of online teaching and instructors new to teaching in the online environment. In order to best understand the richness of the experiences of the seven participants, we chose an interview-based study, as interviews lend themselves to exploring individual points of view and understanding subjective experiences.

This work is licensed under a Creative Commons Attribution 4.0 International License. 


\section{Participants}

Participants from various US and university locations were solicited through an announcement on several professional listservs. A convenience sample of four male and three female participants aged 29-58 was used, and participants $(n=7)$ were all new to online teaching with an initial online teaching experience in the fall 2012 semester. The participants taught in areas including psychology, education, leadership, technology, history and political science. On a scale of 1-5, six indicated they felt somewhat prepared to teach online while one was unsure. See Table 1 for further details about the participants; all participant names are pseudonyms.

All of our participants were asked by their universities to teach an online course as part of their teaching duties. Six of the seven participants indicated in their pre interviews that they were more positive than negative (or even very positive) about teaching in an online environment, while the seventh was teaching online as the only option. As indicated in Table 1, each participant had some experience with prior teaching, either in K-12 or higher education; a few mentioned other informal education situations as well $(n=2)$. Training or professional development preparation for teaching online for the participants ranged from absolutely none, to being a student in a previous version of the class, to being a face-to-face instructor for the same course, to actual training focused on teaching and learning online. Only two participants appeared to have more in-depth training, with one taking part in training for developing online courses (prior to current university association) and another participant taking a four-week training course on how to use Blackboard. One participant indicated that there had been a brief, roughly one-hour, universityprovided workshop.

Online teaching mentoring experiences, formal or informal, were again varied. Five of seven participants indicated they did have a content expert whom they could consult with questions, with three of them being the instructor who developed or previously taught the course. A few participants discussed having talked with these experts prior to beginning their first online teaching experience. Two participants talked about being shadowed in their courses by a more experienced online instructor, with mixed reactions. Others had contact information or knew who they could consult with questions, but these situations were not described as mentoring relationships. 
Table 1

Participants' Backgrounds, Previous Face-to-Face (F2F) Teaching Experiences, and Course Specifics

\begin{tabular}{|c|c|c|c|c|c|c|}
\hline Pseudo & Degree & Gender & $\begin{array}{l}\text { Instructor } \\
\text { type }\end{array}$ & $\begin{array}{l}\text { Previous f2f } \\
\text { experience }\end{array}$ & $\begin{array}{l}\text { Did you } \\
\text { develop } \\
\text { the } \\
\text { course? }\end{array}$ & $\begin{array}{l}\text { Is this } \\
\text { course } \\
\text { new to } \\
\text { you? }\end{array}$ \\
\hline Reba & Ph.D. & $\mathrm{F}$ & Part-time & $\begin{array}{l}\text { Taught } 5 \text { years in } \\
\text { undergrad program } \\
\text { as grad student }\end{array}$ & No & $\begin{array}{l}\text { has } \\
\text { taught } \\
\text { F2F } \\
\text { version }\end{array}$ \\
\hline Dora & Ph.D. & $\mathrm{F}$ & Full time & $\begin{array}{l}\text { Taught } 4 \text { years } \\
\text { graduate and } \\
\text { undergraduate as } \\
\text { grad student }\end{array}$ & No & Yes \\
\hline Allen & MS & M & $\begin{array}{l}\text { Grad } \\
\text { student }\end{array}$ & K-12 experience & $\begin{array}{l}\text { No but } \\
\text { was able } \\
\text { to modify }\end{array}$ & Yes \\
\hline Mike & Ph.D. & M & Part-time & $\begin{array}{l}\text { Taught } 3 \text { years in } \\
\text { undergraduate } \\
\text { program as grad } \\
\text { student }\end{array}$ & Yes & $\begin{array}{l}\text { has } \\
\text { taught } \\
\text { F2F } \\
\text { version }\end{array}$ \\
\hline Dave & MS+ & M & $\begin{array}{l}\text { Grad } \\
\text { student }\end{array}$ & K-12 experience & $\begin{array}{l}\text { No but } \\
\text { was able } \\
\text { to modify }\end{array}$ & Yes \\
\hline Mitch & Ph.D. & M & Full time & $\begin{array}{l}\text { K-12 experience, } \\
\text { taught } \\
\text { undergraduate and } \\
\text { graduate courses }\end{array}$ & No & Yes \\
\hline Sara & Ph.D. & F & Part-time & $\begin{array}{l}\text { Taught } \\
\text { undergraduate }\end{array}$ & No & Yes \\
\hline
\end{tabular}

\section{Procedures}

Each participant completed an online survey to provide demographic data, participated in an initial interview (during the first two weeks of the semester), and a follow-up interview (after finishing their first online teaching experience, approximately week 15 or 16). Based on the initial survey, as well as beginning research questions, the researchers devised an initial semi-structured interview protocol, which was comprised of general and open-ended inquiries about how participants felt about their upcoming experience of teaching online and how they anticipated projecting their personal teacher attributes. Since the researchers and participants were 
previously unacquainted, and did not teach or work in the same college or department, there were few conflicts in power relationships between researchers and participants or challenges due to personal or prior knowledge. Please see Appendix for interview protocols.

\section{Analyses}

The interviews were conducted via telephone, audio-recorded, transcribed, and then analyzed qualitatively, beginning with reading through the entire data set, writing notes or memos as appropriate. As recommended by Creswell (2013), we began by developing a short list of tentative codes or categories of ideas as presented in the interviews. Our findings indicate some similar concerns and perceptions among our seven participants; however, they raised additional issues that are worthy of consideration. The initial codes or categories that were identified as significant areas of concern, interest, or importance to the new online teachers as they developed their online teacher identity are as follows:

- Trepidation about transferring personal teacher attributes to an online environment (e.g., humor, approachability)

- Translation of classroom management techniques, often rooted in traits they associate with their teacher identity (e.g., laidback, friend, authority figure)

- "Social" aspects of course, including appropriate and effective discussions and communication

- Communication with students in an online setting as more difficult and more timeconsuming

- Mixed feelings on control of landscape or environment

- Planning in advance, being organized and keeping on top of things is more vital in online teaching

- Context of workload/ time spent teaching the online course as a concern

- Variety of professional development experiences and their impact or lack thereof on teacher identity development

- Developing a community of practice, including the role of mentors

- Understandings of teacher identity online is different than in traditional contexts

- The 'joy' of teaching in online environments

Next, we identified to what extent these codes were consistent with Beijaard et al.'s four categories identified through review of previously conducted teacher identity research (Beijaard, Meijer, and Verloop, 2004), and these conceptual patterns were re-stated as themes. After analysis of both the initial and final interview transcripts, we compared themes from each data set, looking for overarching themes, patterns or anomalies and, in this way, "abstracting out beyond the codes and themes to the larger meaning of the data" (Creswell, p. 187). This process concluded with the identification of eight major thematic categories, which cut across the entire data set: teaching and humanism, online teacher identity as unique, classroom management, time

This work is licensed under a Creative Commons Attribution 4.0 International License. 
management, projecting teacher presence, communicating effectively, issues of course control, and the role of mentors.

As did Beijaard, Meijer and Verloop, and in sum, we found participant emphasis on development as a process over time, the importance of context, the existence of sometimes-conflicting subidentities (i.e., subject matter expert, face-to-face teacher, online teacher), and the importance of personal agency in class development and/ or instruction. See Table 2 for a breakdown of how our themes reflect Beijaard, Meijer, and Verloop's (2004) four essential characteristics of teacher professional identity. Additionally, we discovered ways that the experiences of the online instructors in our study extended existing understandings of teacher identity development as summarized by Beijaard et al. We address these extensions in the Discussion section.

Table 2

How Themes Reflect Beijaard, Meijer, and Verloop (2004)'s Essential Characteristics of Teacher Professional Identity

Broad themes

Essential characteristics

\begin{tabular}{|c|c|c|c|}
\hline $\begin{array}{l}\text { Identity } \\
\text { as process }\end{array}$ & Context & $\begin{array}{c}\text { Sub- } \\
\text { identities }\end{array}$ & Personal agency \\
\hline
\end{tabular}

Teaching and

$\mathrm{X}$

humanism

Online teacher identity $\quad \mathrm{X}$

as unique

Classroom

$\mathrm{X}$

management

Time management

X

Projecting presence

$\mathrm{X}$

Communicating

X

effectively

$\begin{array}{ll}\text { Course control } & \mathrm{X}\end{array}$

Role of mentors $\quad \mathrm{X}$ 


\section{Results}

In the following sections, we address each of Beijaard et al's four features of teachers' professional identity as they relate to our eight overarching themes. Finally, in the discussion we synthesize the findings and make recommendations for the cultivation of professional teacher identity for online instructors.

\section{Professional Identity as Process}

As discussed by Beijaard et al., profesional teacher identity is not something that is created once and for all and never changed; to the contrary, the conception of teacher self changes over a profesional lifetime as a teacher gains experience in different contexts and develops new personal interests and passions.

\section{Teaching and humanism.}

Many of the participants mentioned their teaching strengths in the pre interviews as being about building rapport or connecting emotionally and intellectually with students. Consequently, many also perceived a difficulty in re-creating similar experiences when teaching online. Specifically, participants were uncertain if they would feel the same enjoyment they had come to know with teaching face-to-face classes. As Allen stated,

I'm trying to picture myself in online classes I've taken, as well-I think that you lose a lot of the joys that you can have in a face-toface classroom, but again, I taught third grade and I loved being with my third graders.

By the end of the term, six of the seven instructors thought their courses were successful and would teach online again. However four participants indicated that they did not enjoy teaching online as much as face-to-face classes, largely due to the lack of personal contact with students:

Jennifer: It sounds like you enjoyed the course.

Dora: Yeah, I did. I still struggle with not seeing the students and talking with them, although part of that . . . I basically told them that they would do better on the final papers if they talked with me, so I got phone calls.

And:

Janet: Do you think it would be fair to say you enjoyed teaching it?

Mike: I think I enjoy teaching in person more. I don't know. If I had to do that for a living, I'd be fine with it. For the rest of my life.

This work is licensed under a $\underline{\text { Creative Commons Attribution } 4.0 \text { International License. }}$ 
I would be happier if I were given an in-person course. The best way to describe it was I really felt more like a secretary than an instructor most of the time.

And:

Jennifer: How would you describe your teaching now that it's over?

Mitch: On the one hand, in the end I believe in the humanness of what I want to achieve when I teach in terms of the relationships I have with the students. Holding people accountable, encouraging and being responsive to questions. I felt I was in broadcast mode and I could never get over the sense of being a radio DJ ...

One conclusion is that the idea of joyful teaching may be re-defined in an online setting. While enjoyment in teaching in a traditional setting may be linked to interpersonal relationships with students developed through conversation, enjoyment in an online setting may be connected to written discourse and closely following evolutions in student thinking over time. The participants in our study were still exploring these differences and will continue to do so throughout their careers as their teacher identities evolve (Alsup, 2006; Akkerman and Meijer, 2011).

\section{Online teacher identity as unique.}

Becoming a successful and productive online instructor is not just a matter of putting all your existing courses online. There are clear and distinct characteristics of online instruction that affect the professional identities of online instructors in profound ways. These characteristics, or realities, of teaching online require instructors to grapple with personal and professional subjectivities that are perhaps unquestioned in a traditional setting. In fact, we argue that online teaching necessitates that instructors re-think, or engage in an interior dialogue with many subjectivities and beliefs consistent with, or even necessary to, face-to-face instruction. To become an effective online instructor one might have to deconstruct and re-build a traditional teacher identity or some traditional assumptions about effective teaching and learning.

Several of the participants indicated they wanted to be themselves in their online courses and be the type of teacher they were in face-to-face environments. However, many expressed at the end of their semester of teaching that being an online teacher is a different animal than teaching in a face-to-face setting. For example, all of the participants expressed concern about how to best establish a connection and sense of rapport with students, a challenge none described as a problem for them in traditional settings. Consequently, they sought ways to meet this challenge through instructor videos, student-driven videos, and Skype. Another unique concern of online instruction involved the conception and execution of feedback. All of the participants expressed concern over how to best respond to student work and discussions, and most believed that in an

This work is licensed under a Creative Commons Attribution 4.0 International License. 
online environment, teacher feedback can be (and even must be) more structured and specific. Dora described her complex transition to online teaching:

Dora: Be patient with yourself. Online courses take a lot of work upfront. Plan weeks in advance. But I'm also really glad that at the beginning I was feeling bad that I hadn't gotten more of the course up, and I'm glad I didn't because I changed and went back to that statement and didn't get too far ahead of me. To find ways to implement your own teaching style.

When previous teachers of traditional courses have expressed identity development challenges or professional concerns, they primarily described issues such as interacting with colleagues and stakeholders, and coming to terms with conflicts between personal pedagogical beliefs and institutionally mandated policies (Alsup, 2006). In this study, the online instructors rarely mentioned any of these issues; they were more challenged by aspects of online instruction that changed the way they interact with students, respond to student work, planned their lessons, and structured their time. Therefore, when moving from a traditional to a face-to-face teaching role, an instructor must re-design course content and re-think his or her teacher behaviors. This coincides with the literature on online learning that we previously discussed, including a shift from teacher-centered to student-centered learning, from passive to active learning, and proximity to students through online communication and presence (Paloff and Pratt, 2002; Hodge, Bosse, Faulconer and Fewell, 2006; Simonson, Smaldino, Albright and Zvacek, 2012; Richardson and Swan, 2003).

\section{Professional Identity Context}

Every teacher teaches in a different school context, with different types of students, and in differing communities. Every teacher has his or her own personal beliefs, ideologies, and preferences that come into play when making pedagogical decisions. Consequently, every teacher must make choices that work within his or her community, school and personal cultures.

\section{Classroom management.}

A major concern during the pre-interviews with participants was the issue of translation from a face-to-face to the online setting (i.e., content, structure, time, adaptability) and how this would impact their teaching and students' engagement. This translation concern was evidenced in participants' discussion of dealing with difficult or unhappy students. Most participants were not overly concerned with so-called classroom management prior to teaching online, and when asked to hypothesize how they might deal with an unhappy or even aggressive student all said they would deal with problems one-on-one with individual students either through electronic communication or phone calls. Overall, they seemed to view these unpleasant interactions as similar, but not exactly the same, in both face-to-face and online settings. However, the online setting held an impersonal feeling for them that complicated such interactions somewhat. For

This work is licensed under a Creative Commons Attribution 4.0 International License. 
example, Sara stated the following when asked how she would handle such a problem in an online course:

Sara: I think what I would do is send them an e-mail and have the conversation with them either over the phone or through Skype. Like the discussion board, I don't go to [it] everyday to see what's going on, and they're not using it very much to [sic] this point, but when I go on and I find they're asking a question and they're lost, I try to address it. Or then if it's a dangerous situation, I'd try to contact the student.

Sara is struggling somewhat with how to have personal, one-to-one interactions with students in an online environment-interesting, considering that Sara is one of the seven participants with the most experience teaching and learning online and who, overall, expressed confidence and comfort with online education. At the end of her course she seems to have figured out some strategies for achieving the desired "personal touch":

Sara: They have to be on top of . . plan their time very carefully. . . especially if you have lots of assignments, you have to be there for your students so they can continue with the next step in the course. . . . Communicate with them, give them lots of feedback. Because it's an online course, it doesn't mean you're not in it together.

Her solution, in part, is increased, careful attention to managing the assignments and feedback provided in the course. Her assumption seems to be that more intense planning is required than for a face-to-face class.

\section{Time management.}

Four of the seven participants talked about issues with time management and the perception of a much higher workload for teaching an online course. Upon further examination of the transcripts it would appear as if some of the course designs truly increased the teacher workload. Assignments created to ensure students were participating and demonstrating their learning were increased from face-to-face course equivalents, including weekly papers and blog entries. This led to frustration for the online instructors, as they could not provide the quantity and quality of feedback they felt was needed; in fact, one participant indicated he was spending more time on grading the weekly activities than truly participating in the course. As Mike explained, "I couldn't really give ninety students feedback on two assignments each week, plus get their material up, plus grade the exams, so that was kind of a disappointment." Coincidentally, this is also an issue that was discussed by Conrad (2004) in her work with initial teaching experiences for online

This work is licensed under a Creative Commons Attribution 4.0 International License. 
graduate instructors, with content and control, or pacing, being one of the major challenges. This corresponds to Beijaard, Meijer, and Verloop (2004) and their identification of a gap resulting from a lack of attention paid to the context of teachers' work (p. 126).

\section{Harmonizing the Sub-Identities}

As in any aspect of life, there are many subjectivities at play within a teacher identity. Teachers have allegiances to and responsibilities for sometimes conflicting constituencies and activities. If these identities conflict too harshly, a teacher may not be able to make coherent, effective classroom decisions. One aspect of teaching online is the shifting balance between teaching and personal time. As Allen expressed:

In face-to-face classes, you can guarantee that there's going to be this time during the week when class meets, you have students with you and need to be on and they're in it, they're going to come at you. But online that can be anytime, 24 hours a day.

Mike echoed:

I can't spend all day Saturday and all day Sunday working on two courses. I don't think any professor does that..it's just too much going on... You have to do it differently, which is not a problem, it's a different challenge. You have to think about it in different terms.

\section{Projecting presence within the course.}

Several participants discussed challenges they experienced projecting themselves and who they perceived themselves to be as teachers. In two post interviews, participants talked about how the highly organized online teaching structure sometimes contradicted what they described as their laidback manner of teaching, built upon rapport with students. One participant, Reba, discussed the challenges she faced projecting her sense of humor, which she sees as a big part of her teaching style:

I love being in the classroom, which made me kind of leery about online education because I didn't know how it was going to translate to the online classroom, but I like to be energetic. I'm humorous, which in some courses-some professors think it's kind of odd that you can bring humor to a [serious topic] course, but I did. I like to be interactive with the students. I love the discussion portions of the class, so I'm hoping that I can translate that into the discussion portions of Blackboard. Mostly I really love to oneon-one interaction with students.

This work is licensed under a Creative Commons Attribution 4.0 International License. 
At least two participants used video technology to help project their teaching personas in addition to building community through course communication tools. As Dave explained,

Every week I had a video of myself kind of speaking to the class and doing a little bit of a recap of the week before and setting up the current week's material and then directing students to look at a couple of things. I backed that up with a written version.

\section{Communicating effectively.}

An emphasis on the importance of communicating in regular and meaningful ways with students, along with a concern about translating this value to the online setting, was mentioned by all of the participants. A related challenge for the participants was the lack of the immediate two-way verbal exchange that is common in face-to-face courses. As Mike described,

trying to effectively communicate without any sort of feedback from a living person right there...this would mean I could, if they emailed me at eleven at night and I checked the email at six that day, or I was going to be traveling or something happened the next day, it might take two days for them to get a simply clarification that would take no more than sixteen seconds in person.

This sentiment corresponded with David's, who explained what he saw as the importance of establishing connections and building rapport early on the course. He explained that while this may be a strength of a teacher working face-to-face, it's more difficult when there is not the immediate two-way communication; for him this was the most difficult aspect of teaching an online course.

When communication worked well in the online setting, our participants expressed feelings of validation. For example, Reba indicated she had received appreciative e-mails from her students:

I wrote more on their papers than they have ever gotten from the instructor and that they really appreciate that I took the time to deconstruct their papers for them, and that made them feel good about what I was doing because I was not just talking to them about the history and how to construct an argument without using, "I think, I feel, I believe." I think that really helped them.

It is apparent that her students really felt her presence and she made herself available to them.

This work is licensed under a Creative Commons Attribution 4.0 International License. 
This issue raises the possibility that activities such as water cooler discussion threads and midterm evaluations could also play a role in guiding novice online instructors as they figure out how to translate their strategies for student communication and supplying feedback to the online setting. An attention to social presence (i.e., the degree to which participants feel affectively connected to one another) and teaching presence (i.e., the design, facilitation, and direction of cognitive social processes) strategies would be one means of facilitating such translation (Richardson, Arbaugh, Cleveland-Innes, Ice, Swan and Garrison, 2012).

\section{Personal Agency}

Professional agency, or empowerment, is essential for teachers to become motivated, confident teachers. Teachers should have a say in their curriculum, daily lessons, classroom management, and profesional development. In this way, they better integrate their personal beliefs and passions with profesional duties and institutional and societal demands.

\section{Issues of course control.}

Our participants presented a full continuum of control over their online courses, from developing the course with total control $(n=1)$ to teaching pre-developed courses with a shadow instructor checking in on their progress $(n=2)$. Also, they expressed a full range of feelings about the level of control they perceived themselves to have over their courses. Four of the participants indicated they had complete control over modifying their courses, and six of the participants were teaching pre-developed courses. Interestingly enough, four of the participants working with pre-developed courses indicated they were content to see how the courses ran their first time out with the prescribed curriculum and didn't mind their lack of control over course design. Two of the three who indicated they had limited control also indicated this was acceptable, while the third participant had hoped to make modifications to the course to improve it but was not allowed to do so.

Such complex and varied relationships with the institutions running the courses likely reflects the reality of how online courses are created, taught, and sponsored: Some universities and colleges ask teachers to both create and teach courses, while others ask designers to create and teachers to only teach. All of our participants expressed that they had at least some control over the direction of their course, even if that meant making changes not officially sanctioned by their university or mentor. Regardless of the degree of control or agency expressed by the instructor, each participant seemed to appreciate positive support and suggestions from mentors and the ability to at least make some changes when necessary.

\section{The role of mentors.}

The participants had very different experiences with mentors or assistance during the online teaching experience. Some had wonderful mentors who provided feedback yet still allowed individual teacher agency. Dave, for example, stated: "One of my very first questions to my

This work is licensed under a Creative Commons Attribution 4.0 International License. 
mentor/ advisor was what degree of control do I have over changing the course. I was really told the sky is the limit."

Additionally, his overall impression from his supervisor(s) was "that if you get stuck, you're not in it alone....go for help..." Alternatively, Mitch's experience with his institutional mentors and supervisors was far from the ideal. In fact, as he stated, it was a teaching experience during which he was stripped of all agency:

Jennifer: What was the most difficult aspect of teaching?

Mitch: My fellow colleague, the faculty member who created this course and wanted me to teach it. Far and away over anything I struggled with was trying to put the soul back into the class.. he is the director of the program, I'm just the teacher of record, and he gave me shit the whole time. In the end it just boiled down to him having trouble letting go of the class; he's a bit of a control freak. My issues were political and not technical.

It is clear that while the new online teachers often welcomed advice and some beginning structure, it was equally important for institutions and mentors to allow instructors freedom to modify courses and make them their own. Individual teacher agency and the power to make classroom decisions have been often cited in K-12 teacher identity research as essential to the development of strong teachers, particularly as they can be fostered through teacher research (see Goswami and Stillman, 1986; Cochran-Smith and Lytle, 1992).

\section{Discussion: What Is an Online Teacher Identity and How Do We Cultivate It?}

In the preceding sections, we outlined the major categories or themes that emerged from an indepth analysis of the interview transcripts from the pre-and post-interviews with the teachers. These themes can be understood as extensions of the four features essential for the development of professional identity, as reviewed and summarized by Beijaard, Meijer, and Verloop (2004): identity development as a process, identity implies and is affected by context, professional identity consists of sometimes-conflicting sub-identities, and the importance of agency (p. 122).

Given that online learning has grown exponentially, with over 6.7 million students taking at least one online course during the fall 2011 term in the U.S. alone (Allen and Seaman, 2013), instructor training and retention is of the utmost importance. Since it is arguable that a satisfying and confident sense of teacher identity is essential for effective teaching and learning to occur, it is important that programs and institutions attend to the needs of new instructors of online courses, even if they are not new to teaching. In essence, if teacher identity is related to the core of the teacher in their particular context, one could say that it also impacts their decision-making in

This work is licensed under a $\underline{\text { Creative Commons Attribution } 4.0 \text { International License. }}$ 
terms of being effective as a teacher. In this research, we discovered that new online teachers have successes and struggles parallel to, yet different from, those of new instructors in face-to-face classes. New online teachers and their mentors can certainly learn from existing teacher identity research; however they must also consider and reflect upon new challenges and concerns-as well as new definitions of success and accomplishment-in an online context. They can also look to the experts to see how they handle issues that are facing them, such as pacing, projecting presence, and managing course workload (Conrad, 2007; York and Richardson, 2012).

This research has extended the definition of teacher identity by describing dimensions unique to online teaching (Paloff and Pratt, 1999, 2001; Redmond, 2011). As teacher identity development is a complex task, comprised of the dialogic negotiation of various subjectivities and propensities (Akkerman and Meijer, 2011), coupled with institutional and contextual realities and expectations (Beaucham and Thomas, 2009; Alsup, 2006; Britzman, 1991; Danielewicz, 2001; Lortie, 1975) and omnipresent social/political forces (Freire, 1968; Apple, 1995; hooks, 1994; Giroux, 2010; Palmer, 2009; and Nussbaum, 1997), successfully educating and mentoring new online teachers is likewise a complex, ongoing process. In the section below we outline some specific, practical suggestions-grounded both in our research and other existing teacher identity research-for preparing and mentoring new online instructors in post-secondary settings.

Based on our findings, we recommend the following for online instructors and the institutions in which they teach:

- Recognize the importance of online teacher (social) presence or sense of self. In this study we listened to our participants struggle with how to project who they were as teachers in an online context. Palloff and Pratt (2001) argue that attention to presence might be more important in an online setting than in a face-to-face setting (p. 8). This coincides with the research in online learning which has shown that expressions of teacher presence impact student satisfaction, perceived learning, actual learning, teacher effectiveness ratings and instructor satisfaction with courses taught (Caspi \& Blau, 2008; Conrad, 2004; Garrison, 2011; Picciano, 2002; Richardson and Swan, 2003; Simonson, Smaldino, Albright and Zvacek, 2012). Social presence has even been shown to play a large part in student retention in online courses and programs (Boston, Diaz, Gibson, Ice, Richardson and Swan, 2009).

- Allow at least some avenues of instructor control over course content and design. While new instructors may have a variable degree of comfort with such freedom, allowing some areas for instructors to make changes based on student needs and instructor preference is important to course success and instructor satisfaction.

- Encourage instructors to use online discussions, interactive technologies and collaborative assignments to enhance teacher-student communication. While new instructors often see discussions and other collaborative, interactive assignments as

This work is licensed under a Creative Commons Attribution 4.0 International License. 
overwhelming, they should be provided with strategies for implementing them effectively and efficiently (Garrison, 2011).

- Mentor new online instructors about the unique needs of online courses, particularly concerning teaching time, management, and structure/organization (Redmond, 2011). Online teaching should be viewed as a unique type of teaching with its own joys, challenges, and pedagogies. Ideally, instructors could share their experiences with online teaching colleagues.

- Provide explicit training about effective teaching, including theories to support best practice and related, necessary technologies.

Teaching online is becoming increasingly common as online courses continue to grow in popularity in all post-secondary content areas and many secondary ones. To meet this ongoing challenge, and as evidenced by this study, those experienced online teachers and administrators should understand that appropriate preparation and mentorship for new online teachers is desirable and essential to successful teaching and learning in online courses in all disciplines. Such preparation and mentorship necessitates approaching online teaching as unique in fundamental ways that must not be ignored or minimized. 


\section{References}

Akkerman, S.F. \& Meijer, P.C. (2011). A dialogical approach to conceptualizing teacher identity. Teaching and Teacher Education, 27, 308-319.

Adams, K. (2002). What colleges and universities want in new faculty. Association of American Colleges \& Universities: Washington, D.C. Retrieved on J anuary 21, 2013 from http:// www.aacu.org/pff/pdfs/PFF_Adams.PDF

Allen, I.E. \& Seaman, J . (2011). Going the distance: Online education in the United States, 2011. Babson Survey Research Group: Babson Park, MA.

Allen, I.E. \& Seaman, J . (2013). Changing course: Ten years of tracking online education in the United States. Babson Survey Research Group: Babson Park, MA.

Allen, I.E., Seaman, J ., Lederman, D. \&J aschik, S. (2012). Conflicted: Faculty and online education. Babson Survey Research Group: Babson Park, MA.

Alsup, J . (2006). Teacher identity discourses: Negotiating personal and professional spaces. Mahwah, NJ : Lawrence Erlbaum.

Apple, M. (1995). Education and power. New York: Routledge.

Baxter, J .A. (2012). The impact of professional learning on the teaching identities of higher education lecturers. The European J ournal of Open, Distance and ELearning, 15(10), 1-11.

Beauchamp, C. \& Thomas, L. (2009). Understanding teacher identity: An overview of issues in the literature and implications for teacher education. Cambridge J ournal of Education, 39(2), 175-189.

Beijaard, D., Meijer, P.C., and Verloop, N. (2004). Reconsidering research on teachers' professional identity. Teaching and Teacher Education, 20, 107-128.

Britzman, D.P. (1991). Practice makes practice: A Critical study of learning to teach. Albany, NY: State University of New York Press.

Boston, W., Diaz, S., Gibson, A., Ice, P., Richardson, J ., \& Swan, K. (2009). An exploration of the relationship between indicators of the community of inquiry framework and retention in online programs. J ournal of Asynchronous Learning Networks, (13)3, 67-83.

Bullough, R.V. \& Knowles, J .G. (1991). Teaching and nurturing: Changing conceptions

This work is licensed under a $\underline{\text { Creative Commons Attribution } 4.0 \text { International License. }}$ 
of self as teacher in a case study of becoming a teacher. Qualitative Studies in Education, 4, 121-140.

Buckley, D. (J anuary/ February 2002). In pursuit of the learning paradigm. Educause Review. Retrieved on J une 28, 2013 from: http:// net.educause.edu/ir/ library/ pdf/ ERM0202.pdf

Bullough, R.V. (1987). First year teaching: A case study. Teachers College Record, 89(2), 39-46.

Caspi, A., \& Blau, I. (2008). Social presence in online discussion groups: Testing three conceptions and their relations to perceived learning. Social Psychology Education, 11, 323-346.

Cochran-Smith, M. \& Lytle, S. (Eds.). (1992). Inside/ outside: Teacher research and knowledge. New York: Teachers College Press.

Conrad, D. (2004). University instructors' reflections on their first online teaching experiences. J ournal of Asynchronous Learning Networks, 8(2), 31-44.

Conrad, D. (2007). The plain hard work of teaching online: Strategies for instructors. Making the transition to elearning: Strategies and issues, 191-207.

Creswell, J.W. (2013). Qualitative inquiry and research design: Choosing among five approaches. Third Edition. Los Angeles/London: Sage.

Danielewicz, J . (2001). Teaching selves: Identity, pedagogy, and teacher education. Albany, NY: State University of New York Press.

Dewey, J . (1916). Democracy and education. New York: Macmillan.

Freire, P. (1970). Pedagogy of the oppressed. New York: Continuum.

Garrison, D. R. (2011). E-learning in the 21st century: A framework for research and practice. Taylor \& Francis.

Giroux, H. (2011). Education and the crisis of public values. New York: Peter Lang.

Gordon, S.P. (1991). How to teach beginning teachers to succeed. Alexandria, VA: Clearinghouse.

Goswami, D. \& Stillman, P. (Eds.). (1986). Reclaiming the classroom: Teacher research as an agency for change. Portsmouth, NH: Heinemann.

This work is licensed under a $\underline{\text { Creative Commons Attribution } 4.0 \text { International License. }}$ 
Higher Learning Commission. (2003). Handbook of accreditation, $3^{\text {rd }}$ edition. Chicago, IL

Hodge, E., Bosse, M, Faulconer, J \& Fewell, M. (2006). Mimicking proximity: The role of distance education in forming communities of learning. International J ournal of Instructional Technology \& Distance Education. Retrieved on J anuary 21, 2013 from http://itdl.org/journal/dec_06/article01.htm.

hooks, b. (1994). Teaching to transgress. NewYork: Routledge.

Huling-Austin, L., Odell, S., Ishler, P., Kay, R. \& Edelfelt, R. (1989). Assisting the beginning teacher. Reston, VA: Association of Teacher Educators.

Lortie, D.C. (1975). Schoolteacher: A sociological study. Chicago: University of Chicago Press.

Nussbaum, M. (1997). Cultivating humanity: A classical defense of reform in liberal education. Cambridge, MA: Harvard University Press.

Palloff, R.M. \& Pratt, K. (1999). Building learning communities in cyberspace. San Francisco: J ossey-Bass Publishers.

Palloff, R.M. \& Pratt, K. (2001). Lessons from the cyberspace classroom: The realities of online teaching. San Francisco: J ossey-Bass Publishers.

Palloff, R. \& Pratt, K. (2002). Beyond the looking glass: What faculty and students need to be successful online, Handbook of Online Learning, 171-185.

Palmer, P. (2007). The courage to teach. NewYork: J ossey-Bass.

Palmer, P. (2010). The heart of higher education: A call to renewal. New York: J ossey-Bass.

Picciano, A. G. (2002). Beyond student perceptions: Issues of interaction, presence and performance in an online course. J ournal of Asynchronous Learning Networks, 6(1), 2140.

Redmond, P. (2011). From face-to-face teaching to online teaching: Pedagogical transitions. ASCILITE Proceedings. Retrieved from http:// www.ascilite.org.au/ conferences/hobart11/downloads/ papers/Redmond-full.pdf

Richardson, J . C., \& Swan, K.P. (2003). An examination of social presence in online courses in relation to student's perceived learning and satisfaction. J ournal of Asynchronous Learning, 7(1).

This work is licensed under a $\underline{\text { Creative Commons Attribution } 4.0 \text { International License. }}$ 
Richardson, J .C., Arbaugh, J .C. Cleveland-Innes, M., Ice, P., Swan, K. \& Garrison, D.R. (2012). Using the community of inquiry framework to inform effective instructional design. In L. Moller \&J . Huett (Eds.), The next generation of education. New York: Springer Publishing.

Rogers, D.L. \& Babinski, L.M. (2002). From isolation to conversation: Supporting new teachers' development. Albany: State University of New York Press.

Simonson, M. Smaldino, S., Albright, M \&Zvacek, S (2012). Teaching and learning at a distance: Foundations of distance education (5th ed.). Pearson: Boston, MA.

Tisher, R.P. \&Wideen, M.F. (1990). Review, reflections, and recommendations. In R.P. Tisher \& M.F. Wideen (Eds), Research in teacher education: International perspectives (pp. 255268). London: Falmer.

York, C. S., \& Richardson, J . C. (2012). Interpersonal interaction in online learning: Experienced online instructors' perceptions of influencing factors. J ournal of Asynchronous Learning Networks, 16(4), 83-98. 


\section{Appendix A}

\section{Initial Interview Protocol}

Can you tell me a little about the course you are teaching.

How would you describe yourself as a teacher?

What type of teacher, online or other, do you aspire to be? Please describe.

What are the most important characteristics that you feel will make you a successful online instructor?

Imagine a challenging moment teaching online, such as a confrontational discussion board posting by a student. How do you think you would handle such a challenge? Describe step by step how you might respond.

What do you anticipate being different in your online teaching experience versus a face-to-face teaching experience?

What would consider a really good experience you have had in a class? Can you provide an example?

What would consider a really bad experience you have had in a class? Can you provide an example?

For both examples do you think this is something that would be paralleled in an online course? Why or why not?

In an online course how do you plan to project your "presence"? Presence can be your personality, your "teacher voice", or even management style. Can you describe what this would look like?

Do you have someone to go to with questions or for support for your online course (technical or content)?

\section{Post Interview Protocol}

\section{Teaching Style/ Strategies/ Redefined}

How would you describe yourself as a teacher of online courses? Has that description changed any this semester?

What were the most difficult aspects of teaching online this semester? What were the easiest? Why?

This work is licensed under a $\underline{\text { Creative Commons Attribution } 4.0 \text { International License. }}$ 
DESCRIBE a really good experience you had in THE class. HOW AND WHY WAS IT A POSITIVE EXPERIENCE TEACHING ONLINE?

DESCRIBE a really bad experience you had in THE class. HOW AND WHY WAS IT A NEGATIVE EXPERIENCE TEACHING ONLINE?

What are the most important characteristics that YOU THINK MADE you a successful online instructor?

Did you enjoy teaching the online course this semester? Why or why not?

(if not already covered elsewhere) DESCRIBE WHAT WAS different in your online teaching experience versus a face-to-face teaching experience. If you transitioned from a face to face to an online version of a course, can you describe how you accomplished that transition?

\section{Presence}

In YOUR online course how DO YOU THINK YOU projected your "presence"? Presence can be your personality, your "teacher voice", or even management style. Can you describe what YOU THINK IT LOOKED LIKE TO THE STUDENTS?

\section{Supports}

DID YOU HAVE someone to go to with questions or for support for your online course (technical or content)? WAS THIS SUPPORT HELPFUL? WHY OR WHY NOT? Previous training - was it helpful?

Did you receive any feedback for this online teaching experience from the students, a mentor, other? What type of feedback (word less directly)

Content (translation to online setting/ barriers to discussion)

Did you feel like you had some degree of control over the course and how it progressed? Did you make modifications? Please describe.

Describe course discussion in the online course/s you taught this semester. Do you think the discussion was useful/successful? How would you define/ describe the discussion in the online course setting? Did it occur similarly to or different than what you expected at the beginning of the semester?

\section{Lessons learned}

If you had 2 pieces of advice to give to a new online instructor what would it be? What would have been helpful to have known going into this experience?

This work is licensed under a Creative Commons Attribution 4.0 International License. 
From the Classroom to the Keyboard: How Seven Teachers Created Their Online Teacher Identities

Richardson and Alsup

WOULD YOU LIKE TO TEACH AN ONLINE COURSE AGAIN? Why or Why not?

If you did teach online again WHAT WOULD YOU DO THE SAME? DIFFERENTLY?

(C) Richardson and Alsup

\section{Athabasca University}

(c) 